\title{
Atrial Bigeminy by ECG Finding
}

National Cancer Institute

\section{Source}

National Cancer Institute. Atrial Bigeminy by ECG Finding. NCI Thesaurus. Code C102596.

An electrocardiographic finding of a sinus beat followed by a premature atrial complexes

for three or more consecutive cycles; a regularly irregular rhythm of normal and abnormal $\mathrm{P}$ waves in a 1-1 ratio. (CDISC) 